\title{
Comparative Analysis of Plateletpheresis Using Different Cell Separators Fenwal Amicus, Fresenius COM.TEC and MCS Plus
}

\author{
Sara Shaikh¹, Muhammad Usman ${ }^{1,2 *}$, Maeesa Wadood ${ }^{1,2}$ and Aisha Shaikh \\ ${ }^{1}$ Baqai Institute of Hematology, Baqai Medical University, Pakistan \\ ${ }^{2}$ Muhammadi Blood Bank and Thalassemia Centre, Pakistan
}

\begin{abstract}
Objective: This objective of the study was to compare the three commonly used apheresis instruments available for Plateletpheresis, i.e., MCS Plus, COM.TEC and Amicus in terms of their Pre and Post donor CBC variables, instrument efficacy and product variables.
\end{abstract}

Methodology: Donors undergoing Plateletpheresis are categorized into three groups. Sixty donors were selected according to the selection criteria of donor for Plateletpheresis by AABB. Later the procedure was performed on MCS Plus, Amicus and COM.TEC. Twenty donors were processed with each instrument.

Results: The study revealed that there is no significant difference in pre and post count of donors on CBC in all the instruments. It is observed that the blood volume processed in order to have the standard platelet yield of $\geq 3.3 \times 10^{11}$ is higher in the COM.TEC as compared to Amicus and MCS plus $(p<0.001)$. The mean separation time for MCS plus is greater than COM.TEC and Amicus $(p<0.001) .95 \%$ of the platelet products collected with Amicus and MCS plus, have a platelet count of $>3.3 \times 10^{11}$. But in COM.TEC, $100 \%$ of the products have a platelet count of $>3.3 \times 10^{11}$. Products collected from Amicus and COM.TEC is leucodepleted. On the contrary, the products by MCS Plus are not leucodepleted. The collection efficiency is significantly low in MCS Plus $(47 \pm 13.6)$ when compares to Amicus $(64 \pm 7.9)$ and COM.TEC $(59 \pm 10.5)$. However, the collection rate is significantly higher with Amicus $(0.07 \pm$ $0.007)$ followed by COM.TEC $(0.06 \pm 0.006)$ and MCS plus $(0.04 \pm 0.004)$.

Conclusion: The study concludes that all kits for Plateletpheresis are very efficient for platelet collection. However, both Amicus and COM. TEC is better than MCS Plus, as they give leucodepleted platelet concentrates. Amicus supersedes all as the target platelet yield is achieved more rapidly as compared to COM.TEC and MCS plus.

Keywords: Plateletpheresis; MCS plus; COM.TEC; Amicus

\section{Introduction}

Platelets are vital in hemostasis [1]. Platelet transfusion is important for the individuals who are at high risk of internal bleeding or hemorrhages. Platelets concentrate are indicated in the therapeutic regimen for medical emergencies such as thrombocytopenia, platelet dysfunctional disorders or prophylaxis that are at risk of bleeding [2]. Platelets are available in two forms depending on the concentration of platelets in each unit. The random unit of platelet contains $\geq 5.5 \times$ $10^{10}$ platelets per unit. However, the single donor platelet $/ \mathrm{mega}$ unit contains $>3.0 \times 10^{11}$ platelets per unit. The mega unit is collected by specialized technique or procedure known as apheresis [3]. Apheresis is a technique which selectively separates the desired component of blood and returned the remainder to the donor through this procedure a large amount of desire component is obtained from one donor [4].

Several comparative studies had evaluated the clinical performance of different plateletpheresis cell separators [5-13]. However, no recent data comparing the Fenwal Amicus, the Fresenius COM.TEC and MCS Plus cell separators was published yet. Therefore, this study was designed to compare the quality of mega unit platelets collected from different cell separators such as Fenwal Amicus, Fresenius COM.TEC, and MCS plus by using different variables such as platelets count, platelet yield, $\mathrm{pH}$ and bacterial contamination of the unit.

The informed consent was taken from the entire selected donor prior to Plateletpheresis procedure. Three instruments were used, including, Fenwal Amicus cell separator, Fresenius COM.TEC and MCS plus devices. Antecubital vein was the choice of vein for venipuncture. The procedures were performed as per the SOPs. In each procedure, the vital sign as well as the adverse reactions was strictly monitored from the beginning till the end of procedure. None of the donors received routine prophylactic oral or intravenous calcium during the apheresis procedure.

The parameters including donors' height, weight, sex, hematocrit (Htc) and platelet count were put into the software in all the instruments prior to the procedure. The proceeded blood volume was calculated to get the platelet targeted yield $\left(\geq 3.3 \times 10^{11}\right)$ in all instruments.

\section{Material and Method}

It was a multicentre study included 60 healthy volunteer donors. The inclusion criteria included, the age of an individual $\geq 18$ and $\leq 55$ $y$, Weight $\geq 50 \mathrm{~kg}$, Hemoglobin level $\geq 12.5 \mathrm{~g} / \mathrm{dl}$, Hematocrit $\geq 37 \%$, Platelet count $\geq 150,000 /$ micro liter, the interval between platelet donations at least 48 hours, with no more than two donations in a week and 24 donations in a year, temperature doesn't exceed $37.5^{\circ} \mathrm{C}$ or $99.5^{\circ} \mathrm{F}$, blood pressure Systolic reading between $90 \mathrm{~mm} \mathrm{Hg}$ and 180 $\mathrm{mmHg}$ Diastolic reading between $50 \mathrm{~mm} \mathrm{Hg}$ and $100 \mathrm{mmHg}$, pulse 50-100 beats/min Absence of any illness, No medication history such

*Corresponding author: Usman M, Institute of Hematology, Baqai Medical University, 51, Deh Tor, Gadap Road, Near Toll Plaza, Super Highway, P.O Box No 2407, Karachi-74600, Pakistan, Tel: +92-21-2224789, Fax: +92-322-3561923; E-mail: staytune1@hotmail.com

Received May 22, 2019; Accepted May 29, 2019; Published June 05, 2019

Citation: Shaikh S, Usman M, Wadood M, Shaikh A (2019) Comparative Analysis of Plateletpheresis Using Different Cell Separators Fenwal Amicus, Fresenius COM.TEC and MCS Plus. J Blood Lymph 9: 247

Copyright: ( 2019 Shaikh S, et al. This is an open-access article distributed unde the terms of the Creative Commons Attribution License, which permits unrestricted use, distribution, and reproduction in any medium, provided the original author and source are credited. 
Citation: Shaikh S, Usman M, Wadood M, Shaikh A (2019) Comparative Analysis of Plateletpheresis Using Different Cell Separators Fenwal Amicus, Fresenius COM.TEC and MCS Plus. J Blood Lymph 9: 247

Page 2 of 4

as steroidal anti-inflammatory drugs and acetyl salicylic acid within the last 7 days. After the detail history donor were screened for infectious diseases, including hepatitis $\mathrm{B} /$ hepatitis $\mathrm{C} / \mathrm{HIV}$ and syphilis and malaria [14].

The informed consent was taken from the entire selected donor prior to Plateletpheresis procedure. Three instruments were used, including, Fenwal Amicus cell separator, Fresenius COM.TEC and MCS plus devices. Antecubital vein was the choice of vein for venipuncture. The procedures were performed as per the SOPs. In each procedure, the vital sign as well as the adverse reactions was strictly monitored from the beginning till the end of procedure. None of the donors received routine prophylactic oral or intravenous calcium during the apheresis procedure.

The parameters including donors' height, weight, sex, hematocrit $(\mathrm{Htc})$ and platelet count were put into the software in all the instruments prior to the procedure. The proceeded blood volume was calculated to get the platelet targeted yield $\left(\geq 3.3 \times 10^{11}\right)$ in all instruments.

\section{Functional Variables}

The functional variables such as processing times, the amount of anticoagulant acid citrate dextrose-A (ACDA), blood volume processed and the flow rate are assessed. All these variables were documented in our study.

\section{Formula for platelet loss}

PLT loss was calculated by the following formula:

PLT loss $=($ pre-PLT count - post-PLT count $) \times 100 /$ pre-PLT count

Formula for platelet yield

PLT yield was calculated by the following formula:

PLT yield=product volume $(\mathrm{ml}) \times$ product count $[($ platelet $/ \mu l \times$ 1000 (Conversion factor)]

\section{Formula for collection efficiency and collection rate}

$\mathrm{CE}$ and $\mathrm{CR}$ were calculated by the following formula:

1. $\mathrm{CE}=$ total PLT yield $\left(10^{11}\right) \times 100 /($ pre- apheresis PLT count + post apheresis PLT count $/ 2) \times$ blood volume processed

2. Blood volume processed $=\mathrm{TBV}$ processed $-\mathrm{ACD}-\mathrm{A}(\mathrm{ml})$

3. Collection rate $(\mathrm{CR})$ was calculated by the formula:
$\mathrm{CR}=\mathrm{PLT}$ yield $/$ separation time

\section{Statistics}

IBM SPSS statistics 17 was used for Paired t- test whereas mean and standard deviation were calculated by Microsoft office excel 2007.

\section{Results}

In this study, 60 selected donors were divided into 3 groups. Each group; comprising of 20 donors, was processed with one cell separator. The Pre and Post Apheresis CBC parameters were estimated. The results revealed that there is no significant difference between pre and post $\mathrm{CBC}$ parameters of all the donors as shown in Table 1.

\section{Instrument efficacy by operational variables}

In this study, the efficacy of all cell separators was determined on the basis of different operational variables. The results of the blood volume processed, the flow rate, ACD volume, separation time and product volume are shown in Table 2.

The mean blood volume processed with Amicus, COM.TEC and MCS plus is $2735 \pm 274.1 \mathrm{ml}, 3342.5 \pm 458 \mathrm{ml}$ and $1922 \pm 86.7 \mathrm{ml}$ respectively. The blood volume processed is significantly higher in COM.TEC as compared to Amicus and MCS plus ( $\mathrm{p}<0.001)$. However, the mean blood flow rate is significantly high in Amicus $(63.3 \pm 6.7$ $\mathrm{ml} / \mathrm{min}$ ), whereas it is $59.15 \pm 3.43 \mathrm{ml} / \mathrm{min}$ in COM.TEC and $28.15 \pm$ $2.97 \mathrm{ml} / \mathrm{min}$ in MCS plus. The mean ACD-A volume consumption in COM.TEC, MCS plus and Amicus are illustrated in Table 2. The mean separation time is significantly higher in MCS plus $(91.15 \pm 1.1 \mathrm{~min})$ than others. MCS plus has the highest extracted mean product volume that is $306 \pm 19.5$, followed by COM.TEC i.e. $266.5 \pm 5.7 \mathrm{ml}$. Amicus has the least extracted product volume with a mean of $252 \pm 4.1 \mathrm{ml}$.

\section{Plateletpheresis product data}

The comparison of plateletpheresis mega unit variables is summarized in Table 3. There is no significant difference observed among Amicus verses MCS plus in the PLT yield/bag ( $\mathrm{p}=1.000)$. COM. TEC has a highly significant yield of platelet as compared to Amicus and MCS plus $(\mathrm{p}<0.001)$. The WBC count of products is evaluated for leucodepletion. The results suggested that Amicus and COM.TEC give leucodepleted products with WBC count of $0.0225 \pm 0.012 / \mu \mathrm{l}$ and 0.003 $\pm 0.001 / \mu \mathrm{l}$ respectively. However, the product extracted with MCS plus is not leucodepleted with WBC count of $1.4 \pm 0.62 / \mu \mathrm{l}$. The mean CE of Amicus, COM.TEC and MCS plus is $64 \pm 7.9 \%, 59.1 \pm 10.5 \%$ and 47.6

\begin{tabular}{|c|c|c|c|c|c|c|}
\hline \multirow[t]{2}{*}{ Donor CBC } & \multirow[t]{2}{*}{ COM.TEC } & \multirow[t]{2}{*}{ Amicus } & \multirow[t]{2}{*}{ MCS Plus } & \multicolumn{3}{|c|}{$P$ value } \\
\hline & & & & C*IA & $\mathrm{A}^{*} / \mathrm{M}$ & $\mathbf{M} / \mathbf{C}$ \\
\hline Pre-apheresis WBC $\left(\times 10^{3} / \mu \mathrm{l}\right)$; mean \pm SD & $7.7 \pm 1.4$ & $7.2 \pm 1.0$ & $6.3 \pm 1.4$ & 0.273 & 0.719 & 0.679 \\
\hline Post-apheresis WBC $\left(\times 10^{3} / \mu \mathrm{l}\right) ;$ mean \pm SD & $7.5 \pm 1.4$ & $6.8 \pm 0.99$ & $6.08 \pm 1.3$ & 0.186 & 0.550 & 0.576 \\
\hline WBC loss, $\%$;mean \pm SD & $2.6 \pm 0.4$ & $2.6 \pm 0.49$ & $2.6 \pm 0.49$ & 0.062 & 0.192 & 0.169 \\
\hline Pre-apheresis Hb level, g/dl; mean \pm SD & $15.4 \pm 0.64$ & $15.0 \pm 0.383$ & $15.1 \pm 0.495$ & 0.518 & 0.212 & 0.137 \\
\hline Post-apheresis Hb level, g/dl; mean \pm SD & $14.6 \pm 0.64$ & $14.1 \pm 0.429$ & $14.1 \pm 0.436$ & 0.010 & 1.00 & 0.021 \\
\hline Hb loss, $\%$; mean \pm SD & $5.2 \pm 1.2$ & $5.4 \pm 0.96$ & $6.2 \pm 1.1$ & 0.369 & 0.030 & 0.008 \\
\hline Pre-apheresis Htc level, \% & $46.2 \pm 1.9$ & $45 \pm 1.1$ & $45.3 \pm 1.4$ & 0.009 & 0.212 & 0.137 \\
\hline Post-apheresis Htc level, \% & $43.8 \pm 1.9$ & $42.5 \pm 1.2$ & $4.25 \pm 1.3$ & 0.010 & 1.000 & 0.021 \\
\hline HCT loss, $\%$; mean \pm SD & $5.2 \pm 1.2$ & $5.4 \pm 0.96$ & $6.2 \pm 1.1$ & 0.369 & 0.030 & 0.008 \\
\hline Pre-apheresis PLT count $\left(\times 10^{3} / \mu \mathrm{l}\right)$; mean $\pm \mathrm{SD}$ & $280 \pm 24.1$ & $282 \pm 37.9$ & $292 \pm 39.7$ & 0.879 & 0.918 & 0.194 \\
\hline Post-apheresis PLT count $\left(\times 10^{3} / \mu \mathrm{l}\right) ;$ mean $\pm \mathrm{SD}$ & $199 \pm 21.9$ & $194 \pm 38.9$ & $198 \pm 42.9$ & 0.667 & 0.625 & 0.298 \\
\hline PLT loss, \%; mean \pm SD & $29.1 \pm 4.1$ & $31.6 \pm 6.3$ & $32.6 \pm 6.6$ & 0.206 & 0.661 & 0.089 \\
\hline
\end{tabular}

$C^{*}$ : COM.TEC; $A^{*}$ : amicus; $M^{*}$ : MCS plus.

Table 1: Significant difference between pre and post $C B C$ parameters of all the donors. 
Citation: Shaikh S, Usman M, Wadood M, Shaikh A (2019) Comparative Analysis of Plateletpheresis Using Different Cell Separators Fenwal Amicus, Fresenius COM.TEC and MCS Plus. J Blood Lymph 9: 247

Page 3 of 4

\begin{tabular}{|c|c|c|c|c|c|c|}
\hline \multirow[t]{2}{*}{ Operational Variables } & \multirow[t]{2}{*}{ Amicus } & \multirow[t]{2}{*}{ COM.TEC } & \multirow[t]{2}{*}{ MCS plus } & \multicolumn{3}{|l|}{$P$ value } \\
\hline & & & & C*IA & $A^{*} / M$ & $\mathbf{M}^{*} / \mathbf{C}$ \\
\hline Blood volume (ml) & $2735 \pm 274.1$ & $3342.5 \pm 458$ & $1922 \pm 86.7$ & $<0.001$ & $<0.001$ & $<0.001$ \\
\hline Flow rate $(\mathrm{ml} / \mathrm{min})$ & $63.3 \pm 6.7$ & $59.15 \pm 3.43$ & $28.15 \pm 29.7$ & 0.031 & $<0.001$ & $<0.001$ \\
\hline ACD-A volume, $\mathrm{ml} ;$ mean \pm SD & $257 \pm 39.5$ & $333.25 \pm 29$ & $320.5 \pm 17.6$ & $<0.001$ & $<0.001$ & 0.067 \\
\hline Separation time, min; mean \pm SD & $52.75 \pm 5.7$ & $63.0 \pm 5.7$ & $91.15 \pm 1.1$ & $<0.001$ & $<0.001$ & $<0.001$ \\
\hline Product volume, mean \pm SD & $252 \pm 4.1$ & $266.5 \pm 10.8$ & $306 \pm 19.5$ & $<0.001$ & $<0.001$ & 0.203 \\
\hline
\end{tabular}

$C^{*}$ : COM.TEC; $A^{*}$ : Amicus; $M^{*}$ : MCS plus

Table 2: The comparison on the basis of operational variables.

\begin{tabular}{|c|c|c|c|c|c|c|}
\hline \multirow{2}{*}{$\begin{array}{l}\text { Plateletpheresis } \\
\text { Product data }\end{array}$} & \multirow[t]{2}{*}{ Amicus } & \multirow[t]{2}{*}{ COM.TEC } & \multirow[t]{2}{*}{ MCS plus } & \multicolumn{3}{|c|}{$P$ value } \\
\hline & & & & C*IA & $A^{*} / M$ & $\mathbf{M} / \mathbf{C}$ \\
\hline Mean PLT yield $\left(\times 10^{11}\right)$ & $3.54 \pm 0.22$ & $4.07 \pm 0.54$ & $3.54 \pm 0.19$ & $<0.001$ & 1.000 & $<0.001$ \\
\hline Mean WBC count $\left(\times 10^{3}\right)$ & $0.0225 \pm 0.012$ & $0.003 \pm 0.001$ & $1.4 \pm 0.62$ & $<0.001$ & $<0.001$ & $<0.001$ \\
\hline Mean RBC count $\left(\times 10^{6}\right)$ & $0.0475 \pm 0.011$ & $0.005 \pm 0.004$ & $0.03 \pm 0.01$ & $<0.001$ & $<0.001$ & $<0.001$ \\
\hline CE \% & $64 \pm 7.9$ & $59.1 \pm 10.5$ & $47.6 \pm 13.6$ & 0.0900 & $<0.001$ & 0.006 \\
\hline Collection rate (PLT 1011/min) & $0.07 \pm 0.007$ & $0.06 \pm 0.009$ & $0.04 \pm 0.004$ & 0.012 & $<0.001$ & $<0.001$ \\
\hline
\end{tabular}

$C^{*}$ : COM.TEC; $A^{*}$ : Amicus; $M^{*}$ : MCS Plus.

Table 3: The comparison of plateletpheresis mega unit variables.

$\pm 13.6 \%$ respectively. The mean collection rate of platelets is highest in Amicus $0.07 \pm 0.007 / \mathrm{min}$ as compare with COM.TEC $0.06 \pm 0.009 / \mathrm{min}$ and MCS plus $0.04 \pm 0.004 / \mathrm{min}$.

\section{Discussion}

As, platelet transfusion is indicated in a number of disorders i.e. leukemia, myelodysplasia, aplastic anemia, solid tumors, congenital or acquired platelet dysfunction, idiosyncratic thrombocytopenia, cerebrovascular accidents and cardiopulmonary bypass [15] therefore new advances are emerging rapidly in this field. For this purpose, various apheresis kits like COM. TEC, Amicus, MCS plus etc. is commercially used to prepare the single donor platelets $[16,17]$. However, no comparative analysis has been conducted among these commonly used cell separators. Therefore, this study was undertaken with the objective of comparing the three different cell separators on the basis of $\mathrm{CBC}$, instrument efficacy by operational variables and product variables.

It is observed that there is no significant difference between pre and post $\mathrm{CBC}$ variables (Hb, $\mathrm{HCT}$, WBC and platelet) among the three groups as shown in Table 1. Consistent findings have been reported by Fevzi Altuntas et al that there is no significant difference between pre and post apheresis CBC parameters of the donors $[13,14]$.

The study was undertaken to analyze the operational variables, including the processed blood volume, the blood flow rate, ACD consumption, platelet collection time and the extracted product volume. The study showed that the mean blood volume processed with Amicus, COM.TEC and MCS plus is $2735 \pm 274.1 \mathrm{ml}, 3342.5 \pm 458 \mathrm{ml}$ and $1922 \pm 86.7 \mathrm{ml}$ respectively. The mean blood volume processed is significantly higher in COM.TEC as compare to Amicus and MCS plus $(\mathrm{p}<0.001)$ as shown in Table 2 . The mean blood flow rate is significantly high in Amicus (63.3 $\pm 6.7 \mathrm{ml} / \mathrm{min})$ as compared to COM.TEC and MCS plus $(59.15 \pm 3.43 \mathrm{ml} / \mathrm{min}$ and $28.15 \pm 2.97 \mathrm{ml} / \mathrm{min}$ ) respectively. Variable ACD consumption is observed with all the three equipments. It is higher in COMTEC $(333.25 \pm 29 \mathrm{ml})$ as compare to MCS plus $(320 \pm 17.6 \mathrm{ml})$ and Amicus $(257 \pm 39.5 \mathrm{ml})$. Regarding mean platelet collection time it is analyzed that the MCS plus requires maximum time for platelet collection i.e. $91.15 \pm 1 \mathrm{~min}$ as compare to Amicus i.e. $52.75 \pm 5.7 \mathrm{~min}$ and COM.TEC $63.0 \pm 5.7 \mathrm{~min}$. The mean product volume from Amicus, COM.TEC and MCS plus are $252 \pm 4.1 \mathrm{ml}, 266.5$ $\pm 5.7 \mathrm{ml}$ and $255 \pm 4.1 \mathrm{ml}$ respectively. The comparison on the basis of operational variables is shown in Table 2.

In our study, the product variables were analyzed which include platelet yield, WBC count, RBC count, collection efficiency and collection rate. The results revealed that the COM.TEC has a highly significant platelet yield as compared to Amicus and MCS plus $(\mathrm{p}<0.001)$. No significant difference is observed among Amicus and MCS plus in the PLT yield/bag $(\mathrm{p}=1.000)$ as shown in Table 2. The WBC count in Amicus and COM.TEC has a leucodepleted product with an average of $0.0225 \pm 0.012 / \mu \mathrm{l}$ and $0.003 \pm 0.001 / \mu \mathrm{l}$ respectively, while MCS plus does not give leucodepleted product with a mean of $1.4 \pm 0.62\left(\times 10^{3}\right) /$ bag. The $R B C$ is significantly low in each technique $(p<0.001)$ as shown in Table 3. Platelet collection is an important variable for comparing these instruments; the new generation of instruments (COM.TEC and Amicus) appears to be more efficient as compared to their old versions. (MCS plus) [5]. This is observed that the mean collection efficiency of Amicus, COM.TEC and MCS plus are $64 \pm 7.9 \%, 59.1 \pm 10.5 \%$ and $47.6 \pm 13.6 \%$ respectively. The mean collection rate of platelets is high in Amicus $0.07 \pm 0.007 \mathrm{~min}$ as compare to COM.TEC $0.06 \pm 0.009 \mathrm{~min}$ and MCS plus $0.04 \pm 0.004 \mathrm{~min}$.

Various studies have been conducted for the evaluation of the different cell separator on the basis of their operational and product variables. The study conducted by Atlantus et al. [14] had reported similar results for COM TEC and Amicus in terms of donor pre and post $\mathrm{CBC}$, operational variables and product variables. However, the result of Strasser et al. [12] was not comparable with our study as they have collected double bag product. The study suggested significantly higher values of the processed blood volume and separation time in COM.TEC. Burgstaler et al. documented median separation times of 77 min for a targeted PLT yield of $5.03 \times 10^{11}$ in Amicus [5]. Additionally, Benjamin et al. decumented average separation times of $71.5 \mathrm{~min}$ for targeted platelets yield of $4.9 \times 10^{11}$ PLT in Amicus [9]. The results were not consistent with our results due to higher platelet yield and separation time in Amicus.

Leucodepletion is one of the important features of platelet product. According to the standards of USA, the WBC count must be $<5 \times 10^{6}$ per concentrate but the European authority $<1 \times 10^{6}$ per concentrate $[18,19]$. It is observed that Amicus and COM.TEC are very efficient in leucodepletion of the platelet product [17]. In view of the above facts, 
Citation: Shaikh S, Usman M, Wadood M, Shaikh A (2019) Comparative Analysis of Plateletpheresis Using Different Cell Separators Fenwal Amicus, Fresenius COM.TEC and MCS Plus. J Blood Lymph 9: 247

it is concluded that new generation cell separators are more efficient as compare to old generation cell separators [20].

\section{Conclusion}

All the plateletpheresis instruments perform plateletpheresis efficiently whereas the new generations of plateletpheresis equipment's such as Amicus and COM.TEC are consistent to obtain a leucodepleted product. Additionally the Amicus, however, has the advantage of a lower separation time, whereas the COM.TEC was the most efficient instrument for the collection of products with higher yields

\section{Acknowledgment}

The author wishes to thank to Muhammad Usman and Maeesa Wadood for reviewing the manuscript and Syed Ehsan Shah, Engineer Tawab and M Sohaib for their technical assistance.

\section{Conflict of Interest}

All authors do not have any conflict of interest to disclose.

\section{Authors Contribution}

Sara Shaikh, Ayesha Sheikh and Maeesa Wadood had conducted the research. Muhammad Usman has supervised the research.

\section{Source of Funding}

The study is non-funded by any organization.

\section{References}

1. Broos K, Feys HB, de Meyer SF, Vanhoorelbeke K, Deckmyn H (2011) Platelets at work in primary hemostasis. Blood Rev 25: 155-67.

2. Blache D (1992) Structure and function of blood platelets. Arch Int Physiol Biochim Biophys 100: 17-24.

3. Hitzler WE (2014) Single-donor (apheresis) platelets and pooled whole-bloodderived platelets significance and assessment of both blood products. J Clin Lab 60: S1-39.

4. Abel JJ, Rowntree LC, Turner BB (1914) Plasma removal with return of corpuscles. J Pharmacol 5: 625-641.

5. Burgstaler EA, Pineda AA, Brecher MA (1993) Plateleta-pheresis: comparison of platelet yields, processing time, and white blood cell content with two apheresis systems. Transfusion 33: 393-398.

6. Beyan C, Cetin T, Kaptan K, Nevruz O (2003) Effect of plateletpheresis on complete blood count values using three different cell separator systems in healthy donors. Transfus Apher Sci 29: 45-47.

7. Burgstaler EA, Pineda AA, Wollan P (1997) Plateletapheresis: Comparison of processing times, platelet yields, and white blood cell content with severa commonly used systems. J Clin Apher 12:170-78.

8. Burgstaler EA, Pineda AA, Bryant SC (1999) Prospective comparison of plateletapheresis using four apheresis systems on the same donors. $J$ Clin Apher 14: 163-170.

9. Benjamin RJ, Rojas P, Christmas S, Neal J, Broughton S, et al. (1999) Plateletapheresis efficiency: a comparison of the Spectra LRS and Amicus seperators. Transfusion 39: 895-899.

10. Moog R, Muller N, Goergens D (1998) Platelet collection with the Amicus and AS.TEC 204 blood cell separators. Transfusion 38: 285-289.

11. Ranganathan $S$ (2007) Comparison of plateletapheresis on the Fresenius AS.TEC 204 and Haemonetics MCS 3p. J Clin Apher 22: 1-4.

12. Strasser EF, Schuster M, Egler K, Bauer J, Weisbach V, et al. (2005) Frequently used plateletpheresis techniques result in variable target yields and platele recruitment of donors. Transfusion 45: 788-97.

13. Altuntas F, Sari I, Kocyigit I, Kaynar L, Hacioglu S, et al. (2008) Comparison of Plateletpheresis on the Fenwal Amicus and Fresenius Com.Tec Cell Separators. Transfus Med Hemother 35: 368-73.

14. Randels MJ (2003) Selection and care of apheresis donors. In: McLeod BC Price TH, Weinstein R (editors). Apheresis: Principals and Practice. Bethesda: AABB Press pp: 131-142.

15. Liumbruno G, Bennardello F, Lattanzio A, Piccoli P, Rossetti G (2009) Recommendations for the transfusion of plasma and platelets. Blood Transfus 7: $132-150$.

16. Coffe C, Benguella M, Domy M, Cottier D, Guignier F, et al. (2001) Plateletpheresis concentrates produced with the COMTEC cell separator: the French experience. Transfus Apher Sci 25: 67-72.

17. Moog R, Zeiler T, Heuft HG, Stephan B, Fischer EG et al. (2003) Collection of WBC-reduced single-donor PLT concentrates with a new blood cell separator: results of a multicenter study. Transfusion 43: 1107-1114.

18. Council of Europe (2004) Guide to the preparation, use and quality assurance of blood components (10thedn), Strasbourg.

19. Fridey JL (2003) Standards for blood banks and transfusion services. (22ndedn), Bethesda: American Association of Blood Banks.

20. Laurencet FM, Doucet A, Lydiate V, Jacquier MC, Mermillod B, et al. (1998) Quality evaluation of plateletapheresis using the new Amicus (Baxter) cel separator: evolution of CD62 expression. J Clin Apher 13: 47-55. 